\title{
Fred Ho's Tribute to the Black Arts Movement: Personal and Political Impact and Analysis
}

\section{Fred Ho}

\author{
Mao and Cabral \\ Mingus and Coltrane \\ Variations on the same tune.
}

Poem inspired by Felix Torres ${ }^{i}$

I came of age in the early 1970s, at the tail end of what Amiri Baraka calls "the Roaring Sixties." By 1970, I had entered my teens and the awakening of my "identity" began. As I have discussed in many previous articles, the black experience catalyzed my own self-awareness as a Chinese/Asian American. I came to identify with the black struggle in drawing parallels with my personal struggle for self-awareness and identity and for the struggle of Asian/yellow peoples as a whole in U.S. society to end racism, injustice, inequality and to achieve self-respect, dignity, and liberation.

Even as a teenager, I intuitively recognized that black American culture and the arts are inseparable from the dynamic of the black liberation struggle. In my youth, I sought to find a comparable connection between the culture and arts of Asian Pacific Americans (APAs) with our liberation struggle for full equality and justice. In a myriad of forms, including political organization, cultural activism, artistic expression and cultural production, I have sought to promote the unity of African Americans and Asian Americans, including forming my core band, the Afro Asian Music Ensemble in 1982 when I first moved to New York City to become a professional artist. In this essay, I want to reflect upon how the Black Arts Movement impacted on my personal development as well as on what I believe to be its impact on the APA Movement and arts. I also want to focus on the importance of the "free jazz" black music on Asian American creative music and improvisation, as well as its organizational influence upon self-production efforts as an assertion of cultural and political self-determination.

Many conscious APAs-meaning those of us who are proud to be APA, politically conscious of our collective history of oppression and struggle in the U.S., and who recognize the on-going, systematic white racism we continue to endure and resist-have admired the black American struggle and especially what we perceive to be the strength, rootedness and communality of the black American cultural experience. Much of the Asian Movement that emerged in the late-60s and early-70s took inspiration politically from the Civil Rights Movement and the Black Liberation Movement. " I continually hear APAs express envy and admiration that I would paraphrase as "I wish we Asians were more [fill in the blank] like the blacks." The "fill in the blank" are generally characteristics or attributes the more conscious APAs feel we as a "people" lack: militancy, radicalism, unity, outspokenness, assertiveness, etc. Sometimes this is expressed as "Where is our Asian Malcolm X? Or Langston Hughes? Or John Coltrane? Or [fill in the name of a leading great black figure]?"

Certainly the black struggle has had a longer and considerably more developed history, and has consequently had a broader and more recognized impact than that of APAs upon American history and society. Much of mainstream America has yet to recognize our presence in American history and society, with the exception of the "model minority" stereotype which has the effect of negating our struggle and portraying us collectively as ethnic successes. However, in a serious study of APA history and political/cultural struggle, there is much to be proud of, to recognize, uphold and celebrate. While we may not have produced historical "giants," we have our inspirational, leading militants and radicals including Carlos Bulosan, Philip Vera Cruz, Yuri Kochiyama, Richard Aoki, Karl Yoneda, Yun Gee, Mitusye Yamada, Merle Woo, Nellie Wong, Janice Mirikitani, and numerous others. Many of these figures, both deceased and living, don't have published biographies or autobiographies. While more biographical profiles and even some books have recently been published, they have little circulation and receive limited attention beyond a small group of conscious APAs. None of our APA giants are "household names."

Until Spike Lee's film $X$, The Autobiography of Malcolm $X$ had withered into relative obscurity during the 1980s, Lee's film was severely criticized and condemned by many conscious black activists and radical intellectuals. They accused Lee and his film of blatant historical distortion and of diluting Malcolm's revolutionary politics, arguments with which I am in agreement. Even among the greater black American population, familiarity with, or recognition and celebration of, radical and militant leaders and movements is a 
lot less common today. These leaders and movements were well known in the period of the '60s and '70s due to the heightened level of the Black Liberation Movement. Today, black "firsts" and celebrities that are often accommodationist, integrationist, and politically less-than-militant are given much more attention by the U.S. mainstream media and educational system. Today's black youth may have only a very superficial and cursory awareness of Harriet Tubman (who organized and led the first black underground militia against the system of white supremacy in the U.S.), the revolutionary views of Malcolm X (such as "capitalism is a bloodsucker," etc.), the Black Panther Party, Assata Shakur, Mumia Abu-Jamal, etc. Indeed, Oprah, Magic Johnson and P Diddy are far better known. Even worse, the only mass media image of yellow-black unity today for both APAs and African Americans is probably the Jackie Chan-Chris Tucker collaboration in the Rush Hour movie series.

But back "in the day" (i.e. Baraka's "Roaring Sixties" and early 1970s) when I was a teenager growing up during this period of accelerated political, intellectual and cultural growth, black-yellow connections and unity were much more real, substantial, meaningful and politically anti-imperialist.

One of the most significant aspects of this period of the late-60s and early-70s was the broad popularization of "Third World" unity and anti-imperialist consciousness and politics. There was much more "mass" popular identification between yellow and black peoples in the U.S. than that which exists today. A lot of this is documented in the anthology which Bill Mullen and I are co-editing, Afro/Asia: Revolutionary Political and Cultural Connections between Africans and Asians in the Americas. In 1964, Malcolm X, in arguing for black American identification with, support for, and even repatriation back to Africa, cited the example of China's growing strength in world politics upon U.S. racist attitudes:

The Chinese used to be disrespected. They used to use that expression in this country: "You don't have a Chinaman's chance." You remember that? You don't hear it lately. Because a Chinaman's got more chance than they have now. Why? Because China is strong. Since China became strong and independent, she's respected, she's recognized. So that wherever a Chinese person goes, he is respected and he is recognized. He's not respected and recognized because of what he as an individual has done; he is respected and recognized because he has a country behind him. They don't respect him, they respect what's behind him.

By the same token, when the African continent in its independence is able to create the unity that's necessary to increase its strength and its position on this earth, so that Africa too becomes respected as other huge continents are respected, then, wherever people of African origin, African heritage or African blood go, they will be respected-but only when and because they have something much larger that looks like them behind them. (211)

During this same era, world heavyweight champion boxer Muhammad Ali, in stating his opposition to the Vietnam War and his draft induction, echoed the mass anti-war slogan of the Black Liberation Movement: "No Vietcong ever called me nigger." Musician Archie Shepp would compare his tenor saxophone to a Vietcong's AK47 as a weapon against U.S. imperialism. In a 1966 issue of Downbeat, Shepp audaciously proclaimed "jazz" to be an artistic expression that was pro-Vietcong (i.e. national liberation) and anti-U.S. imperialism (qtd in Kofsky 64). Many less politically conscious music critics and writers disagreed and objected to such politicization of the music.

What these critics and objectors to Shepp's characterization have failed to understand is the fundamental and quintessential nature of black American culture as a culture of an oppressed people, with its strongest and most vital manifestations as forms of resistance to that oppression by affirming humanity (against inhumanity), beauty (against degradation) and truth (against the lies of racist propaganda and white supremacist ideology).

\section{The Era of Malcolm X and John Coltrane and Third World Political and Cultural Revolution}

It was no coincidence or novelty that the radical and revolutionary intellectuals, artists and activists in black America identified with, looked to, took inspiration from, promoted and participated in the linking of nationalist and radical politics with "jazz," especially the so-called "new music" or "avant-garde" represented by the musical avatar, John Coltrane. 
Socialist-Trotskyite cultural commentator Frank Kofsky makes a self-serving and somewhat contrived connection between Malcolm X and John Coltrane. However, as symbolic statement, and as cultural metaphor, there is much credibility and cogency to the comparison. Malcolm X represented the vanguard "cutting-edge" of revolutionary black nationalist politics. John Coltrane represented the musical and cultural "cutting-edge" vanguard. While no overt connections existed between the two giants, it is clear that they both enormously affected, and were affected by, the Weltanschauung of the era and considerably contributed to, and were shaped by, the zeitgeist of the 1960s. Malcolm X fired the political vision and upsurge in the black liberation struggle in the North American "belly of the beast" to join the world-wide anti-imperialist national liberation struggles waged in Africa, Asia, central and south Americas, and the Pacific Islands. Coltrane fired the music and culture with volcanic energy and irrepressible innovation. Both personified and embodied the apex of black American political and artistic creativity and commitment that was gloriously un-co-optable and unquenchable. In many ways, a dynamic dialectical interplay existed between both political and artistic energies. Political manifestos and position papers by black radical activists often looked to, sought inspiration from, and united with the dynamic energy of the music: "The task of the Revolutionary Action Movement is to express via political action the dynamism embodied in Afro-American music" (Revolutionary Action Movement).

I remember meeting the militant activist Robert F. Williams after his return from exile in the People's Republic of China where he had spent many years with his family. Williams used the term "New African Music" instead of "jazz.",iii

During this time, I wore dashikis along with other black-inspired and influenced urban accoutrements such as platform shoes, bell bottom pants, carried big leather book bags, and emulated my immediate "role models/mentors" such as musician/composer Archie Shepp who had a particularly loping-like gait to his walk, who wore second-hand sheepskin coats during the winter, and who held a cigarette in his right hand as he was playing the keys to his saxophone. Even though I never really was a smoker, my brief attempt to try smoking was motivated to posture like Shepp.

There were other Asians who also closely identified with black culture, though of varying degrees of political sincerity and commitment. I remember one was Robbie Ong, from New York City, who then attended Amherst College as an undergrad, who dressed and danced urban black, lived in a black dorm, who had connections to New York Chinatown through kung-fu and lion dance clubs, who took black studies courses, who played basketball with the black brothers, who spouted the rhetoric of anti-white black cultural nationalism. Robbie was very good looking, closer in facial appearance to icon Bruce Lee than I (as he was of southern Chinese extraction, and I'm much more northern Chinese in appearance). I remember he had a gorgeous West Indian girlfriend. Years later, I would run into him again on the streets of New York Chinatown, now a corporate lawyer in expensive suits, whose only interest in Chinatown was going out to lunch with his white corporate lawyer buddies.

Higher education was the boom industry for the predominantly white community of Amherst, Massachusetts where I grew up. Amherst was known as both the Pioneer Valley for its colonial era roots and as the Five College Area for the growing presence of area campuses such as the University of Massachusetts (the largest) and four smaller private institutions: Amherst College and Hampshire College, Smith College in neighboring Northampton, and Mount Holyoke College in South Hadley. During the Cold War 1960s, public education was a high growth area as the U.S. sought to contend with then-rival superpower, the Soviet Union, by investing into the scientific, technical and professional expertise of its population. The expansion of these five colleges attracted a steadily increasing faculty, staff and student population, which dwarfed the town's population, then of about ten thousand, by seven-fold during the academic season. A growing "minority" (i.e., oppressed nationality) community, the vast majority of whom migrated to Amherst, was also impacting the area.

The children of grad students, staff and faculty of the colleges were diversifying the public school district as well. My two younger sisters and I were among these "minority" students from about 200 APA families in the area, virtually all of whom were affiliated with the colleges. Growing up in this predominantly white community, we faced a combination of white liberal academia "benign" racism along with the racism of the parochial local white rural "red-neck" farming community. Along with the general politicization and heightened social consciousness of the times, the Third World junior 
and senior high school students (which included me) identified with the Third World college students and attended the activities of these area campuses. As high school students, we would go to parties, social events, cultural performances, lectures, and mobilizations at the various "Third World" spaces, especially the New Africa House (a former dorm building at the University of Massachusetts that had been converted to include the offices of the Afro-American Studies Department and Third World student activist offices, a Nation of Islam-run cafeteria, and a hub of cultural and political activities).

While I lived in Amherst, the Five Colleges drew a number of illustrious radical Third World faculty, including artists such as the poet Sonia Sanchez (Amherst College's first chair of Africana Studies); musician/composers Max Roach, Archie Shepp, Reggie Workman, Roland Wiggins, Vishnu Wood, and many others; writers Michael Thelwell, Chinua Achebe, visual artist Nelson Stevens. I especially took advantage of their presence by regularly attending speaking events, performances, workshops and auditing classes. The two classes which impacted me the most were Professor Sonia Sanchez's "Creative Writing and Poetry" and Professor Archie Shepp's "African American Music" ensemble performance class. Since I still was in high school, evening classes were easier for me. I was very interested in Shepp's other lecture class with its bold title "Revolutionary Concepts in African American Music" but it was given only during the day.

I came to New York City in early fall of 1981 to begin a professional life in "jazz." In the summer of 1982, at the invitation of Norman Riley, then directing a Ron Milner play, "Jazz Set," at the Henry Street Settlement Playhouse in the Lower Eastside, with music by Max Roach, I was asked to provide after-play music. This was my first professional opportunity as a band leader. Previously, in Boston, I had organized and led small bands to fundraise for community causes, the main one being to pay the rent for the Asian American Resource Workshop, a cultural and curriculum-development center I had organized and led while living in that city. I formed a sextet featuring three saxophones (because I played sax and knew most readily other sax players) and a standard rhythm section of piano, drums and bass, and called the band the Afro-Asian Music Ensemble. In the early 1990s, at the suggestion of my then-manager, I dropped the hyphen as, politically, I always found hyphenated identities to be problematic. I took the name from the historic AfroAsian Unity conference held in Bandung, Indonesia in April of 1955 which created the "non-aligned movement" of newly independent countries and national liberation movements, and which came to be symbolically known as the "Third World" of Africa, Asia and central and south America and the Caribbean ("Latin America") -independent and self-reliant, and neither part of the First World USA-Western European capitalist bloc, nor the "Iron Curtain" Soviet Union-Eastern European socialist bloc. As my core band for over 20 years, it has been my main vehicle as a composer, baritone saxophonist, performer and leader. My largescale operas, martial arts ballets and music/theater epics have as an instrumental nucleus the AAME.

\section{Black and Yellow Cultural Nationalism}

While it is still highly debated both in general leftist circles and among black radicals whether a "black nation" exists and/or the political implications of "nationhood" (from cultural autonomy to independence), except for a small, self-identified "yellow" nationalist current in the Asian Movement, few dispute that Asian Pacific Island peoples in the U.S. are not an "oppressed" nation (with the clear-cut exception of Hawaii). Black Studies scholar Bill McAdoo has documented the development of the ideology of black nationalism since its inception during the pre-Civil War 1800s. Black cultural nationalism, especially in the late-60s and early-70s, probably most projected and practiced in the Black Arts Movement, with leading practitioners and ideologues such as Imamu Amiri Baraka and Maulana Ron Karenga, adopted an eclectic array of African signifiers and symbolism from assuming new names, taking up new rituals (such as Karenga's Kwanza), donning African styles of apparel, and incorporating African interpretations in artistic forms. Black cultural nationalism has been perhaps unduly criticized for being "narrow nationalism" for its concentration on lifestyle and cultural practice and tendency to deprioritize political struggle (what today would be termed its preoccupation with "identity politics"). The Black Panther Party, in particular, waged vigorous struggle with cultural nationalism, equating it with counter-revolutionary "pork chop nationalism." However, mass organizations such as the Congress of Afrikan Peoples, one of the largest black cultural nationalist groups, were actively and consistently anti-imperialist and involved in struggles to fight police brutality, to run political and economic empowerment campaigns, and to build support for national liberation struggles especially in Africa. What critics of black cultural nationalism have tended not to credit is the role cultural nationalism has played as a counter to white Eurocentric cultural aggression with the promotion of African pride and historical awareness. ${ }^{\text {iv }}$ 
Today, academic Asian American literary critics have applied the term "cultural nationalism" to Chinese American writer Frank Chin and others who vigorously espouse views that promote an "Asian American aesthetic." The implication is that this view is "narrow" and "essentialist." While Chin et al were part of the broad and eclectic rise of the Asian Movement during the late-60s and early-70s, they were not as affiliated, politically, to the Asian Movement as the Black Arts Movement was consciously the "cultural wing" of the Black Liberation Movement. An APA political counterpart to the black cultural nationalist movement was a very small bi-coastal activist circle that espoused the view of an Asian (cultural) Nation. According to veteran activist Mo Nishida, it was primarily based in Los Angeles around people close to the East Wind Collective and New York Asian Americans who had close ties to these people. Poet Lawson Inada wrote an ode-like manifesto entitled "You Know How It Was: An Historical Treatise on the Founding of the New Asian Nation."vi

During the early-1970s, my initial political identity was as a "revolutionary yellow nationalist." My primary ideological framework, while anti-imperialist, viewed the source of Third World peoples' oppression and exploitation as a white hegemonic system called capitalism. I energetically sought to divest myself of European/white influences and acculturation, with primary emphasis directed towards extirpating myself from white social life. I especially oriented myself to African American social life and culture as there was only a very small Asian American community in Amherst, Massachusetts. I maintained a balance of my activism and energies towards both a group of Asian American activists and the bigger African American political and cultural activity in the area. Since my youth, I have fairly evenly shared my focus and involvement between both the Asian Movement and the Black Liberation Movement.

For a brief time, I was attracted to the Nation of Islam and joined as part of my intent to completely divest myself from white society. Two women members of the NOI were especially influential. One was an English teacher in my public school, Marilyn Lewis, who was the first black teacher hired by the Amherst public school system. She was very conscious and introduced the first Black Experience classes, which catalyzed my awakening. She became a very close mentor from whom I sought guidance and direction. She was very warm, accessible and generously gave her time to the Third World students. She particularly took a close interest in me and my Chinese American buddy Todd Lee. We constantly sought her out for political discussions as our identity had been awakened and energized.

Another influential figure upon me, and a towering figure in her own right in the Black Arts Movement, was Sonia Sanchez. I remember Sonia Sanchez for her warmth and accessibility to students. A very short woman, less than five feet tall, thin, and at that time, dressed in Islamic clothing (she had briefly joined the Nation of Islam during the mid-70s), she commanded respect and attention from a crowded room of students. Her own poetry reflected both the vernacular language of urban black America and the poetical. Written words would be spelled differently, almost phonetically, and have a musical quality when she read them. She'd rarely ever use her own works as examples and preferred to have students read their own writings in class. Her creative writing class assignments were all about constantly writing poems and short stories. While she upheld what she termed "didactic poetry or writing" (i.e., "political" poetry and writing), Sonia was never didactic in class, and she set a tone that encouraged student discussion and ease to read in front of the class. She'd encourage feedback and commentary from students, and gave her own criticisms, which never seemed harsh. This contrasted immensely with another writer, who I remember came to one of Sonia's classes as a guest. He sat on a table in the middle of the room and lectured the whole time with his eyes closed as in a "stream of consciousness." There was barely time at the end for discussion. He was an example of a didactic lecturer, unconcerned with the students around him, self-absorbed. Sonia was the opposite, what I now appreciate and recognize as a "dialectical" method of teaching. My friends and I would call on Sonia at home, since her house was near Amherst College. She didn't seem to mind this, and even received us when she was sick. I remember she drove a Mercedes-Benz, parked in the front of her house. At the time, it seemed like a contradiction for a radical to own such luxurious things. While even today I am anti-consumerist and live modestly, I realize that certain "celebrity" artists, and people in general, will have their peccadilloes. However, her revolutionary poetry, respectful and open personality, and genuine humanism far outweighed her owning a Benz.

Archie Shepp, as I came to experience him, was an even more intensely contradictory character. More than any artist, his work and persona has had the biggest impact on me. Even before meeting him, he was larger than life to me. I voraciously read everything about him and interviews with him. 
I bought all of his recordings and sought imports when I traveled to New York City (which had better record stores), and regularly scouted the bins for new releases. What fascinated me about Archie were his outspoken, militant political views; Marxist influences (I later learned he participated in Marxist study circles when he lived in New York City); and his soulful and incendiary tenor saxophone playing. Shepp had moved his family to Amherst when he joined the University of Massachusetts faculty in the early 1970s. His eldest son Pavel (a Russian name possibly from Shepp's wife, now divorced, who is of Russian descent), attended junior high and I came to know him. Pavel played drums in some of my ensembles.

Shepp's charisma comes from his reserved personality and the reputation the press has given him for being such an enfant terrible in "jazz." Shepp irked these music critics by rejecting the term "jazz" which he regarded as "pejorative." At a forum at Sweet Basil's during the Greenwich Jazz Festival in the 1980s, he explained that the word "jazz" came from the French verb "jasser" which means to "chatter nonsensically," or gibberish. Then and today, "jazz" pundits and commentators, most of whom are white males, denounce Shepp's views, especially the ones given most publicity during the 1960s.

When I was around Archie Shepp in the early 1970s at the University of Massachusetts-Amherst, he was notorious for his tardiness, often coming to class at least an hour late, but staying at least an hour longer. His classes often seemed unprepared and improvised. He'd bring in hand-written arrangements of his own and other composers' works and we'd rehearse them over and over again. Fellow UMass attendee, drummer Royal Hartigan, has often pointed out how Shepp allowed anyone to play in his classes, from the most proficient players to the least experienced. Shepp would give everyone a chance to solo, never say anything about how people played. Mistakes would simply be dealt with by repeating difficult passages. While one could complain about the lack of formal rigor in Shepp's classes, his method of teaching was democratic, "proletarian," inclusive and anti-hierarchal; he welcomed everyone's contributions regardless of formal training and expertise.

One of the many strange aspects of Shepp was that he performed pieces at a different tempo than he counted off, but we'd catch on and adjust. Shepp had many harsh critics. A former saxophone teacher of mine, a music department colleague of Shepp's, would vent that Shepp was anti-music, since it seemed he didn't care if things were done correctly or were well-prepared. Many years later l'd come to realize that Shepp's approach was akin to communal ritual; excellence didn't matter so long as everyone was included and shared in the experience of music-making. Shepp's professional bands were for the most part of a high standard. These same critics of Shepp explain this as the result of Shepp being able to hire the top players, a mixture of veterans well-versed in "straight ahead jazz" with the more free music players, ranging from drummers Beaver Harris and Charlie Persip (formerly of the Dizzy Gillespie big band), trombonists Roswell Rudd and Charles Majeed Greenlee (another Gillespie alumnus), bassists Jimmy Garrison, Cameron Brown and Santi diBriano, among so many. This might be a reflection of Shepp's commitment to the continuum of African American music and his refusal to abide by stylistic and generational boundaries. The many sidemen to Shepp's recordings have included top-shelf studio musicians such as bassist Ron Carter and free players such as trombonist Grachan Moncur, III.

While I knew Shepp, he wasn't much of a conversationalist. He'd generally talk in short phrases but, if he wanted to "talk," he was a master of conversational charm and the schmooze. I remember when he called me, needing a baritone sax player to perform (for free) in the musical Lady Day when it was being staged at UMass in 1974. My mother answered the phone and recounted to me how Shepp asked "Is Mr. Fred Houn available?" vii My mother was amused that anyone would ask for me as "Mr." Fred Houn. I spoke to Shepp at length on the phone. He was very loquacious. He even brought up how people had griped about his lateness (and I thought to myself, "did he know I was one of these people?"). He was very pleasant, well spoken and convincing. Shepp is also a writer and is very well-read. Sometimes Shepp's classes became open rehearsals for his own projects or to try out his new works with surprise, heavyweight musicians from New York sitting in. Occasionally, utter chaos would reign when Shepp wouldn't have parts copied or arrangements fully completed. I remember at one evening rehearsal how one of the singers from the male vocal group Reconstruction opened a bottle of wine, which was quickly passed around the room. Since I was then entering the Nation of Islam, I passed on the alcohol, but I remember Shepp was very happy to partake. However, as the class got more disorganized, Shepp raised his voice and said, "Let's not get carried away by the convivialities." Of course, the whole room quieted, both from Shepp's commanding figure but also from his use of such an erudite vocabulary. 
Amiri Baraka, years later as I was driving with him, would remark about how "schizo" Archie was. There's the Shepp who identifies with the urban streets and "jazz" sub-culture and there's the erudite-projecting, petty-bourgeois Shepp who sends his children to private schools, enjoys the finer European luxuries, and who speaks in big words. The raw brilliance and emotive power of Shepp's art flows from who he is. The late baritone saxophonist Kenny Rogers, who I had a chance to meet and briefly talk to when I saw him with the late Rahsaan Roland Kirk in Boston, remarked that "Archie's a genius."

In what today we would call "playing the race card," Shepp was a master. My first experience with him doing this was one of my first classes with him. The class was supposed to take place at a trailer classroom, but it was locked (or perhaps Shepp had forgotten the key). Shepp called Fred Tillis, a black music faculty colleague, and asked Tillis if he could come by and unlock the room. I believe Tillis asked Shepp to call campus security to do this since Tillis probably had finished the day and was at home. Shepp then replied in a tone of well-acted sarcasm, "Now Fred, why would they do that for a nigger?" In a short while Dr. Tillis came by, not too happy, but he did unlock the door.

Years later in New York, I worked with the League of Revolutionary Struggle to sponsor a benefit concert for the LRS's Black Nation magazine, edited by Amiri Baraka. Shepp and Baraka, while once very close cohorts in the early 1960s, even living in the same building in Cooper Square in the Lower Eastside, weren't really friends anymore, but occasionally teamed up for gigs. A year before, drummer Max Roach, a senior to both Baraka and Shepp, brought the two together to join him for a trio performance in Philadelphia that had a huge draw and was apparently a great show. Baraka wanted to do the same show at Columbia University's MacMillan Theater to raise funds for the magazine. Roach bowed out at the last minute (claiming he had to go to Los Angeles to receive an award from Mayor Tom Bradley) and was hastily replaced by drummer Philly Jo Jones. I made the arrangements to contract Shepp. My Afro Asian Music Ensemble opened the show and, during intermission, as the stage was being reset for the headlining trio, Shepp complimented my band and my music, took a swig from a bottle of whiskey and took the stage. Since I knew the three of them hadn't rehearsed and had just spent some pre-show time discussing the plan, I could tell that while Baraka was reading, Shepp was guiding the music, performing on saxophone and piano, various standards and free form excerpts to support Baraka's poetry. While not a great artistic event, the audience was very warm to the three. (However, the event drew about 200 people and lost a lot of money as expectations, largely raised by Baraka, of a full house weren't met. Few "new music jazz" concerts in New York City can draw over 200 people, as I have come to realize, without tremendous marketing, which is costly and usually subsidized.)

Shepp personified the contradictions of a brilliant and talented black man, imbued with a level of political consciousness about oppression, fired with a spirit of struggle and resistance, but mitigated and distracted by his own petty-bourgeois aspirations. While anti-capitalist, Shepp was never clear or explicit about what he stood for in terms of replacing this system. In many ways, he desired to reap the rewards and recognition of the great white counterparts.

Max Roach was another towering musical giant to whom I was exposed during my teenage years. Unlike the younger Shepp, Roach had already entered the pantheon of "jazz" greats since his youthful days playing drums with the great Charlie "Bird" Parker. Roach's credentials and stature were uncontested as one of the premiere architects of modern American music. He was also considered to be The Best Drummer in the World, or one of the best. The only close competitor was the white drummer, Buddy Rich, whom Roach, when I interviewed him in the mid-1970s, called "a friend." I had read interviews of Buddy Rich who, with great respect, recognized Max Roach's considerable artistry. However, unlike Roach, Buddy Rich would get interviews on network television such as Johnny Carson's Tonight Show, or so I believe.

My impression of Max was that he was a very quiet and humble man, but the second he stepped into a room you felt that godhood had entered. He composed a short exercise tune called "Dorian" (based on the Dorian mode) for his students to practice improvisation in three-quarter (waltz) time, with a bridge in three-quarter (walk) feel. The tune became the rage of every student, including non-jazz ones, practiced constantly in campus piano practice rooms. Even Shepp brought an arrangement of it to class. 
In performance there was no ostentation about Roach. He would simply sit at the drum set like a true master, and just start to play incredible, unbelievable music. There was no swagger to his walk, no cool cigarette in his fingers while he played, and little spoken. Once I did see him come out of a luxury Cadillac filled with his family members on a Sunday morning, apparently leaving Sunday church service, and he was dressed in a killer all-white leisure suit with bell-bottom pants. His son Raoul and I were the same age and knew each other in high school. While I never took a class with Max, we'd encounter each other in rehearsals and at events, and he knew I was his son's peer. Years later, as we'd meet professionally in New York City, he'd fondly compliment me, noting how proud he and Shepp were of how much l'd accomplished and achieved. To this day, I've never personally had a disappointing experience with him, though I have known him to lobby for money for his benefit in funding situations. Max introduced me to the concept of black American culture and music as a "continuum," which I adapted to Asian American culture as a diasporic "continuum" that spanned the traditional Asian cultural heritage to the American-created "avantgarde".

Bassist Reggie Workman was also an adjunct faculty at the University of Massachusetts. Workman was less overtly "nationalistic" and more openly related to the white music students. He also paid more attention to musical pedagogical detail than Shepp. Reggie was always prompt and accessible when imparting musical instruction.

The Amherst area has never had another "renaissance" of Third World culture and intellectual activity as it did during this period of the 1970s, brought about by the student and progressive faculty activism that injected radicalism to the "liberal" academic area. The papers of the late great radical and revolutionary scholar-activist W.E.B. Du Bois were housed at UMass. Through the efforts of these activists, the campus performing arts series brought Max Roach's innovative M'Boom percussion ensemble, the Collective Black Artists big band, the play "Ornette," and so many other artists, guest speakers and events.

I met Amiri Baraka for the first time at Hampshire College on the eve of the African Liberation Day demonstration in 1974. There was some disgruntlement expressed over Baraka's honorarium of $\$ 1,000$ (an amount he continued to request well into the 1980 s as I can attest when I was working with him) and that he had required to be flown out immediately after his talk to go to Washington, D.C. for the demonstration. Since I was young and relatively inexperienced, such peccadilloes left an impression, but one far outweighed by the content of Baraka's talk, which was a speech he had written repudiating black nationalism for Marxism-Leninism-Mao Zedong Thought. Baraka's ideological and political move to the left was sending shock waves throughout the black movement and was being closely followed and discussed by many, many others, including those of us in the Asian Movement.

\section{The Black Arts Movement and Its Impact: Multimedia Collaboration as a Third World Thing}

The Black Arts Movement was the attendant cultural wing of the Black Liberation Movement that ignited in the mid-1960s after the assassination of Malcolm X. The BLM (aka the Black Power Movement) included an assortment of revolutionary organizations across the U.S. including the Black Panther Party, the Revolutionary Action Movement, the Republic of New Africa, the Dodge Revolutionary Union Movement (and the other RUMs), the Congress of African Peoples, and many other more regional or local collectives and organizations. The Black Arts Movement included a number of arts and culture-focused groups which were nonetheless as politically-oriented as the political activist organizations, including alternative presses such as Broadside Press, Third World Press, Black World magazine, and Drum magazine. In an excellent yet-to-be-published manuscript by Kalamu ya Salaam on the Black Arts Movement, The Magic of Ju-Ju ${ }^{\text {viii }}$, Salaam summarizes the main characteristics and contributions of BAM:

1. BAM was a national movement, not just centered in northeastern cities, and while Amiri Baraka was the most prominent spokesperson (credited as "the father of the BAM"), the movement had a diversity of organizations around the U.S., including the South;

2. BAM was a popular grassroots movement, not just involving artists and intellectuals, but energized at the mass community level; 
3. BAM was radical and revolutionary;

4. BAM was multi-disciplinary and innovative, and promoted a "popular avant-garde";

5. BAM built independent, alternative, self-reliant institutions not beholden to white funders or support;

As a movement, many of the artists were actively engaged in cross-disciplinary expressions. "Jazz" was the central, fundamental creative gospel that was quintessentially African American, an innovative and sophisticated art form with far-reaching international impact and influence. In African American music in general, but especially in the tradition and practices of "jazz," the primary importance placed upon improvisation (especially in the "free jazz" of the 1960s) signified the unquenchable impulse, desire and aspiration for a musical and creative freedom concomitant with a greater cultural and social freedom from oppression. Unlike improvisation in a "white" new music context, with its emphasis on the arbitrary and aleatoric, African American improvisation emphasized collective interaction and dialogue both among improvisers as well as with the entire culture and tradition of African American musical (and extra-musical) expression. For Asian Pacific American "creative music improvisers," the African American impulse and principles of improvisation greatly appeal to a similar quest and desire to explore our Asian musical heritage and the on-going struggle to assert an Asian American identity and imagination in connection to our confrontation with racism, stereotyping and oppression. We were exploring how the arts in general and music-making specifically would contribute to define Asian Pacific American identity, to build unity, and to empower our people's struggle for dignity, self-respect, and liberation.

Much of African American music is revolutionary (both musically and through its social relevance). Just as the Black Liberation Movement has inspired many other social movements for justice and equality, so too has much of African American culture, especially its music, inspired other oppressed peoples to sing and express their stories, to assert their unique and distinctive cultural identities, to challenge the aesthetic dominance and practices of white settler-colonialist America. I have elsewhere argued that "jazz" is the revolutionary music of the twentieth century. ${ }^{\text {ix }}$ Many "jazz" artists explicitly rejected the term "jazz," deeming it a racial slur or pejorative appellation which the makers of the music - the "jazz" musician—never really invented. Rather, "jazz" is a label that was created by white outsiders. Many of the most conscious musicians preferred to call it "the music."”

The Black Arts Movement asserted and promoted the concept of a "Black aesthetic." Contrary to the criticism of such a notion as "essentialist" (narrow, proscriptive, exclusionary, and dogmatic) the "Black aesthetic" embraced a pan-African scope, asserted and affirmed the presence of African American traditions, forms and idioms, and, by its very assertion, exposed and countered a "white aesthetic" based upon racist Eurocentrism. If anything, "the music" embodied and exemplified the "Black aesthetic" by celebrating African antecedents and interpreted cultural practices, forms and traditions; by valorizing improvisation, exalting "soul" (or the "blues aesthetic"); and by prioritizing innovation and experimentation (signified by a fascination with and appreciation of "hip-ness"). The "Black aesthetic" and "the music" possess formal characteristics such as antiphony (call and response), multiple rhythmic layering, syncopation, soloist-ensemble interplay, etc. The "Black" or "jazz" aesthetic imbued and embodied much of the dance, film, visual arts, theater and literature of this period. Probably the closest interaction was between literature (especially poetry as an oral performing art) and "the music."

Inspired by the notion of a "Black aesthetic," Asian Pacific American artists and musicians began exploring an "Asian American aesthetic" that would include connection and interaction with ancestral Asian/Pacific forms and traditions, with western and popular American influences, and pan-Asian/Pacific hybrid experimentation. Traditional "Asian" aesthetics included both "classical" and court forms as well as "folk" ones. In musical improvisation, Asian Pacific American improvisers not only performed on traditional Asian instruments, but also did so in a "free" improvisatory way (in contradistinction from traditional musical performance). They also began to explore and incorporate Asian "styles" of playing on western instruments such as the saxophone, experimenting with non- and variable temperament, extended non-rhythmic/nonmetrical melodic construction, and other stylistic and technical approaches to evoke aspects of an "Asian" sound as part of an Asian American musical identity, by combining and crossing cultural and musical forms and traditions. For example, in the early 1970s, Japanese American improvising saxophonist Russell Baba went to Japan to study shakuhachi (vertical flute). Upon returning to the U.S. he combined a "jazz" rhythm section with his saxophone and shakuhachi along with Jeanne Aiko Mercer performing on taiko drums.

The BAM generation of black poets could virtually be called "jazz poets" both from their deep and profound appreciation of and usage of "the music" as well as from their close collaborations and social connections 
with the musicians. Many poets performed with musicians or formed poetry bands. Fewer musicians invited poets or sought to utilize poetry in their performances, with the notable exception of Archie Shepp.

Shepp had studied theater and playwriting while he was an undergraduate student at Goddard College in Vermont during the 1950s, and his plays were produced in small alternative theaters in Manhattan's Lower Eastside during the early 1960s. Known for his articulate outspokenness, Shepp was exceptionally literate, a true "Timbuktu" man equally at home in the literary arts, music, and radical political theory. Poetry has been featured throughout his recorded oeuvre. "Poem for Mama Rose" is a tour de force poem by Shepp, a searing indictment of colonialism from the early 1960s, written upon the death of his grandmother. Performed and recorded frequently, ${ }^{\mathrm{xi}}$ Shepp's recitation at once evokes the Baptist preacher, the work hollers of the sharecropper, the blues man, and the militant orator.

They say that Malcolm is dead and every flower is still but I want to tell you Mama Rose that we are the victims...

I want to take this ex-cannibal's kiss and turn it into a revolution...

your corpse turned up to the sky like a putrefying Congolese after the Americans have come to help...

your vagina split asymmetrically between the east and the west...

All of Shepp's poetry is performed with evocative theatrical energy. I have yet to find a poet who can perform/read better than Shepp, who is able to draw from a deep reservoir of musical knowledge and great performative talent.

Another of my personal favorites is Shepp's "Blasé," recorded on the French BYG label while a number of expatriate black American avant-garde artists were in France after attending the 1969 Pan African Festival in Algiers. Performed by the late vocalist Jeanne Lee, the song has been described by one music commentator as one of the most brilliant poetical works on sexual and racial politics. ${ }^{\mathrm{xi}}$

Blasé

Ain't you daddy

You who shot your sperm into me

But never set me free.

This ain't a hate thing

It's a love thing

If love is every really loved that way

The way they say.

I give you a loaf of sugar

You took my womb 'til it runs.

All of Ethiopia awaits you

My prodigal son.

Blasé

Ain't you big daddy

But mama loves you

She always has.

As a teenager, I did my own "cover" of Shepp's "Blasé." In the mid-1980s, I did my own version of Poem for Mama Rose which became part of the libretto to my first opera, A Chinaman's Chance, in a soliloquy called "A Success Story Fable: Poem for Vincent Chin" dedicated to the murdered Chinese American and an 
homage to all victims of racist violence and murder as well as a poetical diatribe against national oppression ("We will always be foreigners in a land where imported music is called 'classical."').

Shepp's stunning and powerful combination of poetry and music would heavily influence my involvement in multimedia performance. Many of my recordings, since my debut Tomorrow is Now!, have featured poetry, text and even graphics as part of my multimedia creative expression. I have collaborated with many poets, particularly African Americans, including Amiri Baraka (we had a new music/new poetry trio in the early 1980s with the late drummer Steve McCall), Kalamu ya Salaam (we were "The Afro-Asian Arts Dialogue"), Sapphire, Louis Reyes Rivera, Esther Iverem, Puerto Rican writer Alma Villegas, Chinese American writer Genny Lim, Tony Medina. I have featured the poetry and writing of many others on my recordings and in my performances, including Sonia Sanchez, Andrea Lockett, Ann T. Greene, Janice Mirikitani, Brian Auerbach, Ruth Margraff, and others.

Former Celebrate Brooklyn festival producer Burl Hash said, "Archie wrote some great and beautiful theater music," referring to the Lady Day musical theater score that Shepp worked on in the early 1970s. Ntozake Shange's choreopoem-play For Colored Girls Who Have Considered Suicide Once the Rainbow is Enuf uses Shepp's music from The Magic of Ju-Ju recording. Shepp prefers to call himself a "folk" musician since he eschews the elitism of the high brow (both concert hall and avant-garde). Indeed, Shepp is both premodern and post-modern simultaneously, drawing upon and juxtaposing elements from the continuum of black culture, interlaced with his familiarity with the modernist European avant-garde, inviting performers who played varying African instruments and blues artists such as Julio Finn, straight ahead players such as Hank Mobley, Roland Hanna, Philly Jo Jones, and others, and electronic musicians such as Jasper Van't Hof, to collaborate with him, with often mixed results. On "Blasé," Julio Finn takes a harmonica solo a half step up in key from the rest of the music, jarring but effective for the tone and content of this dark, disturbing and ominous work.

The 1970s were a transitional period for Shepp, I believe both musically and for the man. As a professor in African American music, Shepp would study, practice and incorporate the broadness of African American musical culture, learning to play chord changes, composing more lyrical and conventional harmony-based songs. The late Romulus Franceschini described this time in Shepp's career as the tenor saxophonist seeking to become more of a pop artist. He was writing and recording vocal songs based on the blues, R\&B, "jazz" ballads, and gospel, including hiring gospel singers. Shepp was himself becoming the bridge in the continuum of black music in America. By the late-1970s, after I had left the Amherst area and had much less contact with him except for attending an occasional performance, Shepp had taken up bebop and playing "jazz" standards as his main repertoire. Yet, his "trickster" spirit would continue to stymie the "jazz" critics. Shepp released two duet albums with pianist Horace Parlan, one of spirituals, and the second of blues songs, that are brilliant in their conception and glorious in the beauty of the simplicity of the material performed with Shepp's idiosyncratic stylization. These two recordings forced once skeptics in the "jazz" establishment to recognize his stature as he won Down Beat Magazine's 1982 Tenor Saxophone of the Year award from the critics. Coinciding with this recognition and certification, a Down Beat Magazine, "Radical with Tenure," stated in a politically self-congratulatory way that the once young '60's militant had "matured" and discarded the avant-garde for the traditional mainstream. How much of Shepp had ideologically “mellowed” isn't clear, and perhaps may never be, as Shepp himself is mercurial.

\section{The Genius and Ego-Mania of Amiri Baraka}

As a young teenager voraciously learning about the Black Arts Movement and the BLM, I found Amiri Baraka's writings to be highly influential. His genius for poetry is widely acknowledged. A target of his poetic and polemical onslaughts has been the black "petty-bourgeoisie" or middleclass, its assimilationistintegrationist orientation and its willingness often to sell-out and compromise the black liberation struggle for token individual gains. Given Baraka's status as a leading black revolutionary artist-activist, it was inevitable that I would study and come to know and to work with him.

By the late-1970s, many of the former leading Third World nationalists in the U.S. had come to MarxismLeninism-Mao Zedong Thought as their ideology. The group I had joined, I Wor Kuen (IWK), merged with a Chicano-based organization, the August Twenty-Ninth Movement (ATM) by mid-1978, becoming the League of Revolutionary Struggle Marxist-Leninist (LRS). A year later, the LRS would merge with Baraka's formerCongress of African People (CAP), to become the Revolutionary Communist League Marxist-Leninist (RCL). I remember the merger celebration in Harlem, January 1979. The crowd of at least two hundred, crammed into a small auditorium, was the largest gathering of blacks and Asians that I had ever seen together. My 
fledgling Afro-Asian music-poetry band, then called Frontline, performed along with the St. Louis-based Infra-Red Funk band, which had formed within the St. Louis chapter of CAP. Two comrades from the former$\mathrm{RCL}$, Kamau and his then-wife Imarisha, would later tell me that the event was truly historic, not just for the political merger and unity, but also because, for the first time, former extreme nationalist comrades of theirs danced with Asians, and that blew their minds! Amiri Baraka was supposed to be the keynote speaker, but after a long delay, he did not show due to an air traffic weather delay that kept him in Chicago. He had phoned in the notes to his speech to Pili Michael Humphrey, a young leader in RCL from Atlanta. Pili's speech was fiery and strong, and I remember to this day one critically important, emphatic point he made in that speech: The national movements were independently revolutionary. The crowd roared its approval as many misconceptions about multinational unity and the national question in the $M-L$ movement tended to be integrationist: that nationality-in-form organizing was "narrow" and inherently "lesser" than multinational formations of organizing. Such a white integrationist position implicitly, and sometimes explicitly, suggested that uniting with majority-white leftists was "more" revolutionary than all-black or all-Third World peoples' formations. Pili's statement, which was the position of the LRS, made it clear in no uncertain terms how we as a Marxist-Leninist group stood on the national question.

It was at the event after-party, while dancing to the Infra-Red Funk band, that I developed a crush for one of the former-CAP-RCL comrades, Jamala Rogers. She was short, broad shouldered, voluptuous, dark-skinned with a beautifully rounded face. It wasn't until the early 1990s, after the split and dissolution of the LRS that we'd begin dating. I was the first non-black man she ever dated. I'd take her to see Chinese films, have meals in Chinatown, take her to Baja and La Jolla to enjoy the ocean beaches. When I visited her in St. Louis, we visited the black rodeo, a black independent free school. She jokingly referred to us as "renegade lovers" since we were both outcasts from the anti-socialist majority that had seized control of the LRS by 1989. After several months of a long distance relationship, I broke us up realizing that we would never live together as neither she nor I were willing to relocate from our beloved home bases of St. Louis and New York City.

Part of the work of the merger with RCL involved quickly clearing out its former office in Newark because it was condemned to demolition. I was still living in Boston at the time, but traveled down to New York City frequently for meetings and for my own enjoyment. The Big Apple was much more exciting than Bean Town. Here were the cultural and political "names" and the amount of activity was staggering. On one of my trips, I stayed with an LRS comrade in Chinatown who shared a passion for "the music." One night we attended the debut concert of the World Saxophone Quartet at the Public Theater. A who's who of black artists were there, including Amiri and Amina Baraka, sitting a table away from us. Steve introduced us to them and they politely returned the greeting. The next day, a group of us from New York went to Newark to the CAP office and combed through the boxes of files, record albums and videos. It was amazing the amount of black liberation movement history that we had to throw out as we could only take what we could carry. I remember reading some files that had copies of "Chairman" Baraka's articles sent to various periodicals, and the rejection letters. One I remember in particular explained its rejection of Baraka's submission by stating "We don't publish advocacy."

Kalamu ya Salaam assesses Baraka's contribution as the BLM's greatest "propagandist," while Modibo, a CAP-RCL veteran, believes Baraka was "one of the great organizers in the BLM." Certainly during the peak period of the CAP, more than a dozen chapters nationwide were organized. Baraka played a leading role at the National Black Political Convention in Gary, Indiana; in organizing many cultural benefits, festivals, alternative theater, presses (e.g., Jihad Publications) and cultural campaigns; and in the struggles and organizing work of the African Liberation Support Committee. His history of work and accomplishments is prodigious. As with any great leader, a strong and capable circle of supporters greatly contributed to the successes and accomplishments. But what is noteworthy compared to today was that these organizing efforts were done by activist volunteers, with virtually no paid staff. This is distinct from the non-profit organizations today that have hired staff and rely upon state- and corporate-funded budgets. However, when the movement waned, Baraka seemed to lose touch with the new realities and conditions. When I began to work with him in the early 1980s, CAP-RCL had faded to only a handful of chapters nationwide. The organizational base and infrastructure was far weaker than a decade before, yet Baraka seemed to operate on the notion that simply by the sheer force of his will could the same level of activity continue. People have marveled and wondered about his immense productivity. When I asked his wife Amina about it she explained that "Amiri has such a strong focus of concentration; he can write even if a party is going on around him." Indeed, Baraka, unlike the sybaritic behavior of other artists, is very Spartan and is constantly in motion, intellectually by his constant writing and polemicizing, and physically by his ability to go from event 
to event. He does relax, as I've run into him at "jazz" clubs and shows from time to time. He likes to "hang out" and converse over a beer or burger.

One of the criticisms of the RCL was its dogmatism and over-reliance upon quoting the classic M-L-M texts. I believe much of our movement of that period was infected by Stalin's interpretation of dialectical materialism. Indeed, Stalin's short book, Dialectical and Historical Materialism, was a movement primer and classic text used in study groups. Stalin tended to view most contradictions at a level of being antagonistica battle with the enemy. Politically, he tended to characterize most contradictions as "either/or" in which one true, proletarian position fought with the enemy, bourgeois line. There was very little synthesis or view of reality as a complex interpenetration of opposites, but rather, as two stark and diametrical opposites for which the one correct line had to vanquish the incorrect one. Baraka possesses much of this influence. On the positive side, Baraka is one of the few Marxist intellectuals and theorists to give sharp, analytic political assessments of artists and cultural trends. However, his views about the "class struggle" in African American literature and in "the music" reflect draconian hard-line positions that place artists either in the camp of the people's tradition of struggle or in the camp of "tail Europe" (white assimilation and capitulation to western imperialism). If one has been categorized by Baraka as "tail Europe," it won't persuade anyone to rethink his or her musical and political direction. ${ }^{\text {xiii }}$

Baraka can be a scathing critic, but he also is able to offer programmatic proposals. I've often looked to his "manifestos" for ideas about HOW to create alternatives. For example, his call for a cabinet position on the arts for the U.S. government has merit. His call for certain American films and important cultural icons to be certified as national treasures of art so that they won't be sold to Sony or foreign multinational corporations is also a valid reform. I've learned that every critique should come with a proposal for an alternative. Yet today, Baraka, possibly suffering from delusions about his own role as agitator-propagandist, is either incapable of, or won't do much, ground-up organizing. Exhortations can't substitute or replace the crucially necessary day-to-day, grassroots work that is so lacking in today's U.S. left. The cadre of people who will do this work in a disciplined, professional (but inevitably unpaid) collective mode is what we lack.

For all of Amiri's great accomplishments and impact, his greatest weakness is his inability for true, honest, soul-baring self-reflection. While much ado has been made about his changes in identity and politics from LeRoi Jones (Bohemian beat poet) to Imamu Amiri Baraka (cultural nationalist) to Amiri Baraka (Marxist leftist), in all of his poetry and writings, there is very little personal feeling and self-criticism beyond the coldly ideological and political. Unfortunately, he is caught up in his own cult of personality. Often his ideological and political battles become personality wars and are dismissed by many as such, which harms the political message and position. His ad hominem attacks, through his frequent use of "the dozens" as a form of "dissing" his ideological opponents often leave a bad taste as simply ridicule. A recent example was his ferocious condemnation of Ralph Nader supporters in the 2000 presidential elections, accusing those who voted for and backed Nader against Gore of having delivered the presidency to rightwing fascism represented by Bush. In some ways, his continual fascination with electoral politics since the days of "black electoral empowerment" strike me as social-democratic: socialism in words but supporting the Democratic Party in deeds. In recent years, his temper has become testier. In my opinion, except for his poetry, his writing has become sloppy and sometimes even incoherent. ${ }^{\text {xiv }}$ His role continues to be primarily as a propagandist-agitator though his effectiveness as an organizer and as a "leader" has significantly diminished with his incapability to unite and train new cadres and organizers. He continues to be a scrappy warrior-artist who is bold, brazen and brilliant in his rapier-like attacks and critiques of the U.S. white racist ruling class. Without showing any signs of "mellowing" (i.e., increasing ideological and political conservatism), Amiri Baraka as poet-warrior continues to fight when many others have capitulated to career self-aggrandizement.

\section{Unity and Struggle with Kalamu Ya Salaam}

I met writer, poet, producer and cultural activist Kalamu ya Salaam ${ }^{\mathrm{xv}}$ in spring of 1989 while my Afro Asian Music Ensemble was at the Houston International Festival, invited by then-curator Ms. Baraka Sele. Baraka had told both Kalamu and me that we had to meet each other, so a dinner between us, along with others who were traveling with each of us, took place in an upscale restaurant. ya Salaam and I had known of each other for a while but had never met personally. I knew him from the Black Scholar debates between black nationalists and Marxists in the early to mid-1970s, a historic transition period in the black liberation struggle, with much discussion within the African Liberation Support Committee. ${ }^{\text {xvi }}$ The ALSC was a broad black activist united front to build support for the African liberation struggles in then-still decolonizing countries such as Rhodesia (now Zimbabwe), Guinea-Bissau, Mozambique, South West Africa (now Namibia), Angola, and South Africa and it had the leading exponents of black nationalism and the emerging Marxist 
current in the black liberation movement. ya Salaam at that time was anti-Marxist and pro-pan-African cultural nationalism, joining with Haki Madhubuti (poet-activist, formerly Don L. Lee), and others, against Amiri Baraka (who had been a leading cultural nationalist and had just turned to Marxism), Mark Smith and a group of North Carolina-based black leftists including then-Revolutionary Workers League leader Owusu Sadaukai (then Howard Fuller), Abdul Akalimat (then Gerald McWorter), and others. By late spring 1976, in my second semester at Harvard, I too had moved from my revolutionary yellow nationalism to Marxism through the influence of the young Marxist organizers on campus (particularly from a small Boston-New York collective called the Proletarian Unity League). But during the winter of my sophomore year (late 1976-early 1977) I joined I Wor Kuen, having more unity with them on the "national question."

Kalamu ya Salaam and I were cautious with each other in our first meeting, but each of us asked the other about our views on a number of topics. He attended our performance at the festival the next day. I left our initial encounter with a positive impression. Soon after, I took the initiative to telephone him at his home base of New Orleans. We talked further about politics and the arts. I was very positive about his accessibility and openness to me, which differed from the narrow nationalist impression he'd given me through the published debates. I directly asked him if he was a socialist and he replied that he supported socialism as a system to replace capitalism but didn't identify as a socialist/Marxist because he believed the ethics of socialism were far more important to him than the theory or ideology. He continues to self-identify as a pan-Africanist, but has formally renounced black nationalism. ${ }^{\text {xii }}$ I proposed that we work together in a poetry/music duo and he agreed.

I had just joined a progressive speakers/performers agency called Speak Out: Artists and Writers, which had received its initial start-up from $Z$ Magazine, a progressive political periodical headed by leftist Michael Alpert, but, as I would soon learn, decidedly anti-Marxist, especially Marxist-Leninist. ${ }^{\text {xiil }}$ Speak Out had found me a gig to perform at the University of Michigan-Ann Arbor and I suggested that it become a duo with Kalamu, to promote African-Asian American unity. The sponsors liked the idea and I immediately called Kalamu, and he agreed to join me. Kalamu also took the initiative to call his contacts in the Michigan area, professor and writer Melba Joyce Boyd and white militant poet-activist John Sinclair, and he found an extra gig for us at the campus at which Melba was then teaching. Kalamu's initiative impressed me. Our performances together went off very well.

Kalamu ya Salaam is truly a "jazz" poet who is adaptable, flexible, unfixed to a set way of reading/performing his poetry-the creative interaction of a true "jazz" musician. A number of other "jazz" poets with whom I've performed were fixed and stiff; I was supposed to simply follow their set way of reading. There was no interplay between their poetry and my baritone saxophone performance. Kalamu can actually interact and interplay with my improvisations. While he, too, like many of the other "jazz poets," called for "jazz" standard tunes to be the framework of many of his poems, he wasn't stuck on just following these melodies and could hear my transitions and departures and new directions and join with me.

As good friends, comrades and artistic collaborators, Kalamu and I have enjoyed much in-depth discussion, debate and ideological struggle on a wide range of issues. He has shared much of his thought processes, experiences and opinions, including his book manuscript analyzing the Black Arts Movement, The Magic of $J u$-Ju, which is with Haki Madhubuti's Third World Press for publication. For the most part, I believe Kalamu "walks his talk." Upon reading his manuscript, I thought it was a major work of great importance for understanding BAM from a participant's point of view and with valuable insights, information and analysis. I offered to help him find a publisher but, true to his pan-African nationalist convictions, he wanted the manuscript only to be considered by a black publisher, and for it to be targeted to black bookstores and to a black audience, though perhaps a white left small press may have published it more quickly and offered better distribution. Kalamu has often said that his audience is a black one first and foremost. He hasn't sought to "cross over" to a white poetry or arts audience or institutions. He is a cultural producer, having produced radio programs, festivals, and publications of black poetry and music through black organizations, even though some have been less-than professional in their business dealings. He explains his interest in the music and poetry, as well as his interest in China, as having been sparked by the work of Langston Hughes. Hughes had made recordings of his poetry with "jazz" and had written poems, especially during the 1920s and '30s, that expressed internationalist solidarity with the peoples' struggles around the world, including the poem, "Roar, China, Roar!" for the Chinese revolution. Kalamu ya Salaam shared with me the costs and work of organizing our "Afro-Asian Arts Dialogue." xix

Kalamu ya Salaam is an ardent cultural activist who is firmly committed to black independent cultural production and has self-published many anthologies as well as his own poetry chapbooks. He had criticized 
an edition of the African American Review devoted to the topic of "the music" when it didn't even include one black writer. The Review offered him the opportunity to edit another volume on the same topic in 1995, for which he included predominantly black writers, but others as well, including myself and Irish American drummer Royal Hartigan. ya Salaam also introduced me to Christopher Small's book on "the music"-Music of a Common Tongue-which, at the time of the early-1990s he considered the best analysis and understanding of "jazz." His own insights into "the music," his analytic writings about music and African American culture in general, have been for the most part very insightful. I remember during the time of our first Afro-Asian Arts Dialogue performing at the University of Wisconsin-Madison with Peggy Choy, we had lunch with a "jazz" professor who seemed to believe the black "free music" avant-garde was halted and replaced by the rise of commercial "fusion jazz" in the 1970s. Kalamu took exception and cited another current, the rise of the CTI record label and other black fusion-funk music with such artists as Donald Byrd (a hard bop trumpeter-composer-band leader) and the Blackbyrds (a band of his Howard University students who played much more commercial black urban dance music). Kalamu ya Salaam also asserts that "jazz" is a "world music," as the black jazz musicians were among the black community's first "internationalists," touring overseas and returning to their communities with an internationalist understanding. Kalamu has always asserted the social importance of "the music" and black culture. His was the only voice of criticism about Clint Eastwood's film about saxophonist-composer-titan Charlie Parker, Bird. ${ }^{\mathrm{xx}}$ More than anyone, Kalamu has, I believe, best understood the impact and importance of John Coltrane upon black music and culture, an idea that has shaped my views in this article. In an interview with Kalamu ya Salaam, Bill Mullen asked what he felt about my opinion about the "enormous" impact of Coltrane. ya Salaam replied that Coltrane's impact was "beyond enormous," which I concede is indeed the truth.

Kalamu ya Salaam and I have worked well together as artists, and have shared many hours of debate and struggle over ideological and political questions. He is a close friend. Our unity has its limitations, consistent with Kalamu's nationalism. As a nationalist, Kalamu obviously hasn't taken as strong an interest in learning about the APA history, struggle and experience as I have taken towards African Americans and Africa. But my greatest disappointment with Kalamu comes from his deliberate silence in criticizing the leading reactionary in "jazz" today, Wynton Marsalis, and Marsalis' right-wing ideological advisor, Stanley Crouch. Kalamu knows that Marsalis' opinions about avant-garde musicians (that they can't read music and lack technical rigor for the traditional aspects of "jazz") are misdirected, just as they were thirty years ago when the very same charges were leveled at the 1960 s avant-garde. The avant-garde chooses to make music differently, and its merits or faults should be judged not by the criteria of "straight-ahead mainstream jazz," but by its own.

To my knowledge, the two most critically explicit opinions voiced about Marsalis by leading black artists were from now-deceased musicians Lester Bowie and Julius Hemphill (the latter charged Marsalis to be an "Uncle Tom" in the pages of The Nation and other national publications). I have discussed my own criticisms of Marsalis elsewhere. ${ }^{x \times i}$ Suffice it to say, I'm of the position that Wynton Marsalis is to Lincoln Center what Clarence Thomas is to the U.S. Supreme Court: a black neo-conservative, right-wing, second-rater.

My admiration and friendship for Kalamu continues despite our disagreements and differences. His commitment to cultural organizing, to independent black cultural production, to education and training within the black community based in the south is exemplary and an affirmation of Cabral's fundamental principle of national liberation movement building for artists and activists to "return to the source."

\section{Creating a Popular Avant-Garde: How the Black 'New Music' Inspired Asian American Creative 'New Music'}

The "avant-garde" of a colonialist western Europe or white North America isn't necessarily politically progressive or transgressive, and may indeed reinforce privilege, promote solipsism and self-indulgence, oppose social responsibility and consciousness, and elevate "art for art's sake." In contrast, the "avantgarde" of oppressed peoples' cultures generally tends to fuel liberation, challenge cultural dominance and hegemony (usually of the oppressor, colonial traditions, and forms), and to promote rebellion, struggle, dissidence, disturbance, militancy, and opposition to the status quo. The African American "avant-garde" of the 1960 s and early 1970 s was such a force. The "new music," "new poetry," and "new theater" etc., were part of a cultural and social movement for a "new society." In a broad sense, the artists sought to "deconstruct" the "old" society of white supremacist, Eurocentric patriarchal capitalism for a "new" society based on full equality, social justice, and "power to the people." The terrain of struggle for these "avantgarde" transgressors was as cultural activists, though many also contributed through their social activism as well. Of course, the "new" jazz with Coltrane as avatar was the most potent and compelling wave of artistic 
experimentation and expressive force. As the late trumpeter Lester Bowie explained, in retort to neoconservative "back to the tradition" exponents à la Wynton Marsalis, "The tradition of jazz IS innovation."

Asian Pacific American artists took inspiration and example from the African American avant-garde. APA creative improvisers were neither interested in being traditionalists by replicating classical or folk Asian forms, nor could we identify much with the white avant-garde, especially since their own privilege and racism often excluded us while they, as cultural imperialists, unabashedly appropriated Asian forms and influences. The black avant-garde was politically radical as it emanated from the Black Arts Movement and we Asian American radical artists wanted to raise the consciousness of our communities, to create a radical Asian American cultural wing and expression and to experiment with mixing and combining different forms and disciplines. Improvisation allowed us the "space" to boldly go beyond where our ancestors had been, beyond the European concert and American popular cultural modes, to explore a new cultural identity called "Asian American." We didn't want to be measured by how well we played traditional Asian forms, how well we played conventional western popular song forms, how well we played notated music. We wanted to discover what it meant to be Asian American through music. "Free jazz" was a huge inspiration because we could hear the revolution. We could express the truth of our emotions about oppression (what some have described simplistically as the "rage" of "free" music); dare to be Asian American in defiance of stereotypes, of proscriptive roles and idioms; and not kow-tow to any musical order or establishment. Improvisation was about expressing the "yellow soul" during the hey-day of "yellow power." No truer, more elemental expression could be evoked, as we explored, deconstructed, re-visioned all of the musical materials of our heritage. The tradition of improvisation, of an unremitting quest for freedom, paralleled the overall tradition of oppressed people to reject complacency, accommodation, the seduction of assimilation and integration in favor of a constant struggle to challenge the status quo, and ultimately, to make revolution and thereby construct a truly multicultural American identity predicated upon the right of self-determination for oppressed peoples. In that fundamental sense, we shared the radical character with the black avant-garde.

I would assert that the early black avant-garde beginning with Sun Ra in the 1950s and extending to the Art Ensemble of Chicago in the 1960s and '70s, were precursors and leading examples of a "black postmodernism." The Art Ensemble of Chicago's mantra, "Great Black Music: Ancient to the Future," best signifies the self-conscious reworking, borrowing, re-interpreting, and musical juxtaposing and collaging in their collective performance rites. Sun Ra's cosmic theory, Julius Hemphill's fascination with the Dogon, are just two examples of this Afrocentric "post-modernism" that seeks to understand the past with an avantgarde sensibility. Sun Ra was the preeminent forerunner to today's fascination with extraterrestrial contact/visitation and inter-species communication joined with hopes for world peace and unity through man's connection to the extraterrestrial. I disagree with people who try to explain Sun Ra as a manifestation of Space Age modernity. Rather, Sun Ra's fascination with the extraterrestrial is much more about spirituality than a fixation upon technology, though certainly Sun Ra was interested in the latest electronic musical instruments. For Sun Ra, music and space exploration would point the way for humanity to develop a higher consciousness of the need for a changed orientation beyond the limitations of earthly material acquisitiveness.

The late-1970's and early-1980's avant-garde in New York's loft scene, however, was, in my opinion, weaker as an example of vulgar post-modernism that promotes obfuscation, obscurantism and empiricism. These black avant-garde musicians and artists of the 1980's New York Soho loft scene had retreated into self-indulgence (hiding or jettisoning their former socially conscious work) and jumping on to the white performance art band wagon of Meredith Monk, Philip Glass, Robert Wilson, Richard Foreman and others. The fire of the '60s and early '70s had dissipated into esotericism, ambiguity and shallow post-modern pastiche by African American artists who even questioned "blackness" as essentialist, including Bill T. Jones, choreographer Donald Byrd, Bebe Miller, Carl Hancock Rux, among others.

Just as African American popular culture has a leading influence upon American popular culture in general, so too does African American avant-garde music have a similar impact upon the overall avant-garde. A small but important group of APA musicians embraced "the music" and its philosophical, political and cultural radicalism. My other essays discuss the who, what, where, when, and why of the so-called Asian American Jazz "scene" on both coasts, so I won't repeat any of that discussion. Multi-woodwindist Gerald Oshita, bassist Mark Izu, woodwindist Russell Baba, clarinetist Paul Yamasaki, and east coast violinist Jason Hwang were "free jazz" players exploring Asian musical and performance concepts. I met Gerald Oshita before he died in his Japantown studio in the early 1980s. He had a large collection of woodwinds, including a number of unconventional and uncommon ones, which reminded me of Rahsaan Roland Kirk who performed on the manzello and the stritch. In the opinion of Asian American jazz impresario Paul Yamasaki (who helped to found and organize the first annual Asian American Jazz Festival in the Bay Area), Gerald 
warranted props as the first Asian American to be on a Soul Note/Black Saint recording (as a sideman/colleague of Roscoe Mitchell). The Italian-based label was considered by many to be the "creative new music" label of the 1980s. In 1984 I would become the first Asian American to record as a leader for that label, eventually releasing three recordings and having one of my pieces recorded on a fourth, a recording by the Rova Saxophone Quartet. My first Soul Note album earned much notice both from the circle of Asian American jazz artists as well as from the larger "creative new music" circle, both for the significance of my outing as an Asian American band leader but also for my explicitly radical politics and "Afro-Asian" concept.

One overlooked Asian American composer/musician/band leader of the late-1970s and early-1980s was the Los Angeles-based Chinese American Benny Yee who, with singer Noboku Miyamoto, had a band called Warriors of the Rainbow. Yee had the musical skills to play chord changes and to go between "free jazz" improvisations and notated arrangements, whereas most of the others mentioned above were primarily "free" improvisers. Warriors of the Rainbow enlisted highly skilled African American sidemen, including trombonist Julian Priester and saxophonist Bennie Maupin, who had played with such greats as Herbie Hancock, among many others. As the name of their band might denote, it was a multicultural assemblage (Asian and African) and politically militant ("warrior" or "warriors" was commonly an African American conception of someone engaged in the struggle for liberation).

As a young Asian American musician, I sought other Asians playing in primarily black bands, though many were not very politically conscious. Many were Japanese nationals who embraced and identified with "jazz" and black music for its cultural iconoclasm, hipness and alternative lifestyle and cultural norms. I haven't met a Japanese national who played excellent "jazz" that is motivated and inspired by and identifies with black nationalist or explicitly anti-imperialist politics.

Indeed, "jazz" is a cultural commodity of exotic fascination in Japan where lucrative touring possibilities have existed for black American artists, as they do in Europe. However, in accounts told to me by Japanese American drummer Akira Tana, and other Asians (even Japanese nationals), the tour promoters have at times explicitly told American band leaders not to bring Asian musicians on their tours. White or black artists are viewed as more "authentic" or exotic, while Asians are viewed to be "inauthentic" and, thus, less interesting for marketing purposes.

The Asian American "jazz" scene was much more active on the west coast, with the most radical and "free" music centered in the Bay Area. The "scene" could be grouped into three loosely connected styles: a "jazz fusion" scene with its most prominent group the Los Angeles-based band, Hiroshima, along with Deems Tatsukawa in Seattle, and others; a mainstream straight-ahead "jazz" group, mostly older generation players such as Filipino pianist Bobby Enriquez, pianist Toshiko Akiyoshi, alto saxophonist Gabe Balthazar (of Stan Kenton big band fame), the younger drummer Akira Tana (whose professional career started from touring with the Heath Brothers); and the "free" creative music players. To George Leong and Paul Yamasaki's credit, when they first organized the Asian American Jazz Festival in the Bay Area, all three styles were featured, even if some of the artists didn't particularly identify with Asian America. Another scene which claimed the term "Asian American music" was a pop folk-music style of Asian American performers including the east coast trio A Grain of Sand and west coast groups such as Yokohama, California, the subsequent projects by Robert Kikuchi-Yngojo, a loose gathering of musicians based around San Francisco's Japantown Art and Media Workshop, among others. The Japanese American taiko groups were another subset of self-consciously organized Asian American musical activity. Except for the "straight-ahead jazz" players, most of the artists and organizers of all these "scenes" identified with the Asian Movement and community.

The bands Commitment on the east coast (three black musicians and Jason Hwang) and United Front in the Bay Area (Mark Izu with the half Japanese-half black drummer Anthony Brown, and two black horn players), were primarily "new music" jazz-focused, though they did perform occasionally at Asian community events.

Rarely have musicians developed any sustained and coherent collaborations across these scenes, possibly due to stylistic differences and the lack of artistic leadership and skills to bridge such differences. However, pioneering efforts between the creative new music "jazz" artists such as Izu, Baba, myself and later artists such as Jon Jang, Miya Masaoka, Glenn Horiuchi, and Francis Wong would incorporate traditional instruments and players in cross-stylistic collaborations. 
One other major scene that has never really embraced, much less identified with, the Asian American Movement or community is the world of individual "new music classical" composers who have incorporated traditional Asian instruments and elements into high brow concert music, such as: Chou Wen-Chung, Chinary Ung, Chen Yee, Chou Long, Bright Sheng, Tan Dun, Ushio Torikai, Toru Takemitsu, etc. These composers more typically subscribe to the "art for art's sake" position and seek legitimation from the musical academy and Eurocentric establishment.

\section{Alternative Cultural Production: The Rise and Fall of Black Artist Collectives}

The Black Arts Movement spawned numerous alternative, community-based collectives and guerilla-style organizations in all disciplines. For music, the most well-known and influential groups were the AACM (Association for the Advancement of Creative Musicians) in Chicago and the BAG (Black Arts Group) in St. Louis. I named my first multimedia "performance art" group, the now-defunct Asian American Art Ensemble, after the famed Art Ensemble of Chicago, a collective music group that emerged from the AACM that presented ritual-style performances with the musicians in African-mythological-inspired make-up and costumes combining indigenous "primitive" instruments with modern saxophones, drum set, and bass. The late-60s and early-70s black alternative music organizations promoted Afrocentrism, multimedia and experimental performances with a strong grassroots community orientation and collective musical sharing and organizational decision-making. They were attempts to create alternatives from the band leader-as-star syndrome, to foster creative dialogue, to promote unity over stylistic differences, and to collectively build a cultural movement closely aligned with the black liberation struggle.

By the late-1980s, Bay Area-based Chinese American pianist Jon Jang had started his own record label, AsianImprov Records (AIR) to release his own music. By early 1988, Francis Wong and I joined Jang to expand the concept in the effort to become a leading center of "Asian American jazz" or "Asian American improvised and creative music" as part of exerting cultural leadership to the Asian Movement since we were all part of the League of Revolutionary Struggle (Marxist-Leninist) at the time.

Our record label and production company was modeled on the early black creative music collectives. The first non-Jang recording was my A Song for Manong (AIR 003), a collector's edition LP that featured my Asian American Art Ensemble in collaboration with the Filipino American Kulintang Arts which performed primarily traditional southern Philippines kulintang music but was open to creating contemporary work as well. The score I composed became the third part in a large music/theater production Bamboo that Snaps Back! which recounts the resistance struggles of Asian Pacific Americans. A Song for Manong celebrated the epic struggles of the Filipinos beginning with the arrival of Magellan in 1522 to the fall of the International Hotel in San Francisco Manilatown in 1977.

By the late-1980s, many of the black alternative cultural collectives had either collapsed or gone the route of social service arts-in-education providers. None maintained the radical, experimental, avant-garde performance thrust. A newer "movement" was Mbase, centered around alto saxophonist Steve Coleman with Brooklyn and New York City black musicians. However, it quickly faded as many became disgruntled and disillusioned with it for simply promoting Coleman's career interests. Elsewhere in Brooklyn, MOBI (Musicians of Brooklyn Initiative) had been started by Lester Bowie and others, and had incorporated as a non-profit arts organization. But musicians quickly left $\mathrm{MOBI}$ believing that it only served the bigger name artists as a conduit to get grants.

In forming my own production company, Big Red Media, Inc. in 1998, I recognized that the collective "movement" was dead since the political sensibilities and leadership that were a direct result of the Black Liberation Movement had disappeared. Former collective-functioning artists were more interested in pursuing solo careers. This was the same experience that undermined the early-60s October Revolution movement started by trumpeter Bill Dixon for the purpose of being a black creative music collective that would break from the recording industry. However, as Dixon tells it, October Revolution member Archie Shepp was secretly negotiating his own record deal with Impulse! during this time. Shepp's position was that he needed the money to pay for the costs of his growing family. Other members quickly became disenchanted and the group fell apart.

Collective artistic and financial/business decision-making can only be viable if the artist members totally submit to the governing mission and principles and are truly able to function collectively, putting self-interest secondary to the goals of the movement. This is especially challenging for artists who necessarily have very big egos and strong personal visions. In the 1930s, similar types of alternative and artist-led "unions" 
attained a certain level of impact and collective functioning because they were secretly led by communist cadres. Such collectives require a strong political core that will resist cooptation and careerism.

In the 1970s, black nationalist recording labels also developed, including Strata-East in New York City and Black Jazz in Chicago. While I am unknowledgeable about the history and final outcome of Black Jazz, I was around the music scene in New York to hear gossip about the demise of Strata-East, about musicians absconding with money, or that the label simply failed as a viable business. An alternative distribution company, the non-profit New Music Distribution Service, also collapsed by the early 1980s as well. Certain lessons can be made from all of these experiences about alternative cultural organizing:

1. Grant monies are unreliable; a strong political core leadership must exist to maintain the collective context;

2. Artists must share in the business work and expect their returns to be contingent upon their shared input;

3. The collective must be a guerilla enterprise and rely upon its own earnings.

My production company isn't a collective; As a private company, I bear all profits and losses. Therefore all final decisions are mine. I believe that in this era, without strong political leadership from movement organizations or a revolutionary party, we can enter into mutually beneficial alliances that are primarily or strictly for business interests. Simply sharing the same political ideas and values doesn't make for a viable business alliance. Indeed, the primary consideration if we are to function with gain, and not from altruism, must be serious business principles. We must continue to work with community-based and movement organizations, however, but not maintain professional expectations. Indeed, I still believe in building benefit concerts and cultural events for the Movement, but no one should expect to be paid (though these events should sell artist merchandise, which can be very successful).

Since the 1990s, a new wave of younger APA "spoken word" and hip hop-identified artists have organized their own performance opportunities, self-produced recordings and self-published chapbooks, APA student tours, and even national conferences. Like the earlier Asian American music scenes, these younger artists continue to struggle with questions about Asian American aesthetics and cultural production, including: What makes for a unique and distinctive Asian American artistic expression? How do we make professional careers being APA artists doing APA art when no infrastructure exists within our communities to support these endeavors? What are our standards? How does our art-making and work relate to the broader APA communities, including campuses, immigrants and to APA activism? Who is our audience? What kind of institutions/businesses do we need to build?

While many of these APA hip hop/spoken word artists recognize the major influence and inspiration of blacks and Latinos in the development of hip hop culture, there is much variegated opinion about APA interpretations and expressions ranging from the imitative to the innovative.

By the 1990s, interest in "Asian American music" and "Asian American jazz" had begun to grow among a few cultural studies and Asian American Studies professors, including a survey course taught on this topic at the University of California-Berkeley by pianist Jon Jang. A few articles by Susan Asai, Su Zheng, Weihua Zhang, Yoshitaka Terada, Joseph Lam, and others have begun to appear in ethnomusicology journals. ${ }^{\text {xii }} \mathrm{A}$ few conferences have included topics on Asian Americans in music. The Asian American Jazz Festival in the Bay Area continues annually, and a short-lived east coast festival was organized in the mid-1980s by the Jazz Center of New York (led by Cobi Narita) with curatorial support from artists including myself, Jason Hwang, Akira Tana, and others. Other small community festivals of Asian American creative music have occurred in Boston and Chicago. Ethnomusicology conferences have occasionally hosted performers as well. Taiko, kulintang and more traditional "ethnic" concerts occur more frequently as part of folkloric celebrations and ethnic heritage festivals.

\section{Phoney Afro-Asianisms and the Way Forward}

During the mid-1990s, the Asia Society of New York City sponsored two consecutive annual Asian American jazz festivals, both of which occurred virtually unnoticed and had low audience attendance. The Asia Society also tried to host an event with African American and Asian American artists which was also a dismal failure, and towards which I took an adversarial position by demanding my usual performance fee which the Asia Society declined to meet, thus precluding my involvement. They had asked my collaborator Kalamu ya 
Salaam in the Afro-Asian Arts Dialogue to come; he agreed and then tried to convince me to appear with him at a very reduced fee. I later spoke to another invited participant, poet Sonia Sanchez, who confirmed that the event was a sham since she never received her honorarium. For almost a half century, since its founding, the Asia Society had ignored Asian Pacific Americans, as well as controversial topics on Asia and the Pacific Rim, such as the Vietnam War, socialist China and Korea, the revolutionary and national democratic struggles in the Philippines, Nepal, Burma, etc. Rather, their focus was on teaching exotic Eastern culture to, as someone described it, "the wives of Upper East Side business men who have business dealings and clients in the East." xxiii "The topic of APAs would inevitably broach such controversial issues as racism, discrimination and inequality. Since its inception in the late-60s and early-70s The New York Asian Movement has always regarded the uptown, arrogant and elitist Asia Society as a legacy of U.S. colonialism in Asia, part of the problem of exoticizing and othering the "East." For example, the Asia Society hired white executives in their organization until the 1990s when the first Asian directors were finally hired. One of the biggest insults and travesties of their Asian American Jazz Festival was failing to invite me, a leading Asian American "jazz" artist who has had an impact on both coasts and who lives in New York City! Although repeatedly asked by some press writers and curious individuals familiar with my work why I wasn't invited, the Asia Society has never given a public explanation.

Another emerging topic is African American and Asian American relations. A couple of conferences, one at Columbia University in 2000 and another at Boston University in 2001 were both organized by African Americans at these institutions. Smaller forums and panels have also been organized in different cities, mostly by academics. Most of these events have only minimally included the arts or artists. All have ignored the longstanding work that I have done in this field. The fascination with the topic of "black-Asian conflict," sensationalized by the mainstream media during confrontations between Asian (usually Korean) merchants in predominantly African American communities, wrongly presumes that there is a special "conflict" of more importance than a "black-white conflict," or a "black-Latino conflict." With the waning of Third World consciousness and unity from the late-60s and early-70s which I have described earlier in this essay, it is not surprising that division and conflict have arisen. Certainly examples of Third World unity and collaboration have never received media attention except for the crassly commercialized neo-minstrelsy of the Jackie Chan-Chris Tucker Rush Hour movies of today. The Rush Hour movies don't even have the fraction of the politics of say, the 1973 blockbuster Enter the Dragon with famed Chinese martial artist the late Bruce Lee, and black American Jim Kelly playing a black militant character on the run from the police, who remarks about the poverty and oppression he sees in Asia, "Ghettos are the same around the world. They stink." Among the most highly at-risk youth populations, the martial arts have been a site of much black-Asian-Latino-poor-white inner-city interaction between popular culture (kung-fu Saturday afternoon movies on local television stations) and individual and collective uplifting (as training for self-discipline, personal and community security, building self-esteem and confidence). While scholarly investigation, analysis and study of the systemic roots of Third World division are important to an anti-imperialist consciousness, many of these academic conferences and forums are mired in self-referential language and topics and don't attract or reach out to community participants. It would be better if we had Third World film and cultural festivals, activist workshops, and community forums. But the key to building Third World unity has been coalitions and alliances forged in common struggles, both for local issues and for international solidarity.

The building of our respective movements requires ideological development through the course of building grassroots struggles and organizations. A radical, anti-imperialist and revolutionary thrust of our organizing and propaganda must be central. The anthology, Legacy to Liberation: Politics and Culture of Revolutionary Asian Pacific America, has attempted to summarize, analyze and share the lessons of the revolutionary and radical formations and struggles of the late-60s/early-70s and to connect this legacy to today's organizing for the Asian Pacific American Movement. Such projects need to be developed for the Black Liberation

Movement, the Chicano Movement, the Puerto Rican Movement, the Native Movement, etc. At the same time, collaborative anthologies, be they artistic-cultural or political, across oppressed nationality movements, need to be developed as well. To get beyond the multi-kulti "racial" unity reformism that proceeds from the premise that unity is mostly attitudinal, we must reaffirm the importance of the oppressed nationality struggles in the U.S. as "national questions" based upon the struggle to control land, resources, and economic and political power with a common enemy, the system of U.S. imperialism. Afro-Asian unity isn't simply the appreciation of each other's cultures and experiences, but is a historical outgrowth of the need for alternative political paradigms that are independent from U.S. white-settler colonial integration and western European hegemony. Oppressed nationalities can share the lessons of their common struggles and build solidarity, inspire one another and construct a new paradigm that doesn't subscribe to the racialized welfare line and participate in the divide-and-conquer competition over crumbs constructed by the white power structure and its token compradors. Once we've "de-Europeanized" our orientation, looked to the Third 
World (both domestically in the U.S. and internationally) as our main allies, and have grounded ourselves in an internationalist, global, world "anti-imperialist" orientation, we can begin the task of truly decolonizing and disentangling ourselves from the tentacles of imperialist cultural and economic domination, and begin the forward march to liberation and world unity.

\section{Notes}

' This short three-line poem was inspired from a similar poem written by Felix Torres in the late 1970s when he and I were student-activists at Harvard University. Felix shared his poem with me and I was inspired to write the one used here as an epigram.

ii See Ho "Legacy to Liberation" for a more complete discussion and analysis of the beginnings and inspirations of the Asian Movement in the U.S.

iii I met and conversed with Robert F. Williams while he was on a speaking tour sponsored by the U.S.-China People's Friendship Association when he visited the then-Chinatown People's Progressive Association during the winter of 1977 or 1978 in Boston.

${ }^{\text {iv }}$ For a comprehensive history of the Congress of Afrikan Peoples (CAP), see the very hard to find Forward \#3, the journal of the then-League of Revolutionary Struggle (Marxist-Leninist), Getting Together Publications (now defunct), published in 1979.

"A number of Asian American literary critics have used the descriptor "cultural nationalist" when applied to Asian American writers such as The Four Horsemen of Asian American Literature (viz., Frank Chin, Lawson Inada, Shawn Wong, and Jeffrey Paul Chan), including leftist-feminist critic-scholar Cheryl Higashida in her essay, "Not Just a 'Special Issue': Gender, Sexuality, and Post-1965 Afro-Asian Coalition Building in the Yardbird Reader and This Bridge Called My Back." In my role as editor for this anthology, I gave Cheryl the following critique of her (and others') usage of "cultural nationalism" when applied to Asian/Pacific American writers and artists in my March 27, 2004 email to her: "Be careful with characterizations as 'cultural nationalist' as Chin, et. al., never adopted this description, nor did the Asian movement of that day do that either (whereas the Panthers did characterize Baraka and Karenga as 'cultural nationalists'). The similarities between the black cultural nationalists and the Asian ascribed ones needs elaboration as the Asians rejected any romanticism of their ancestral Asian heritage. Therefore, I think you need to do an analysis of what from the Black Arts Movement was taken and what was originated by the Asians."

vi During the early 1970s, in my personal files, Poet Lawson Inada had inscribed "Written to commemorate the first New Asian Nation Poetry Reading." The full text of the poem is as follows:

Course you know how it was.

But I couldn't think of anything more fitting to

Commemorate this occasion.

So I thought l'd just run it down to you.

That was way, WAY back,

You know those famous dates,

But those first ships knew exactly what was happenin'

The heaviest minds in all of Asia had seen to that

But they didn't quite plan on meetin' up again with

Their long lost brothers,

Those who had cut out when things were bad

Now, those brothers have their own culture going

And a beautiful way of being and seeing

Not too different from our own,

Naturally, we got together, grooved on things together

And naturally, left the land and animals as they were

We knew better, 
Remembering how some of the 'old folks' tried to Mess our homeland up

We knew better

But also, knew about the ghosts across the oceans

So decided to set up defensive measures in small Parts of our lands just to keep the ghosts Off our backs

Then things REALLY got nice

That was the start of this New Nation as we know it

People-yellow, brown, black and red-going back and forth, Or settling, exchanging wisdom and gifts,

We joined our lands together

We had so much to share with each other

So when the ghosts came crawling with their crosses to our shore

We sent 'em south

Burdened down with their monstrosities of war

Figurin' to let 'me take out their primitive aggressions in the jungles

You know their funny books

About how some Washington drowned in the Amazon crossing there With a cannon on a canoe

While how some dude named Boone got chewed up by piranhas

While wrestling a python.

Those ghosts were CRAZY!

SHIT!

They tried to carve their faces on a mountain and then they fell flat

On their collective ass

And about that time we got hip that some of our best brothers were

Settled there anyway, really doing beautiful in the jungle

So we got together and tossed the ghosts back to their land we call

OKLAHOMA

You KNOW what that means in our language

So if you still see some of those ghosts around,

TAKE PITY

HELP 'EM OUT

It's our duty

They knew they were foolish and called us in to give them color and Culture,

So they too could flourish

TAKE PITY

Couple of more generations and they'll be colored, and together,

And beautiful like the rest of us

And you KNOW that's how it's supposed to be!

\footnotetext{
vii I was known as Fred Houn until the fall of 1988 when I legally changed it to Ho, phoneticizing a problematic spelling of Houn, which was always pronounced $\mathrm{Ho}$.

viii This title is taken from the 1967 recording of the same name by Archie Shepp.

ix See Ho, "What Makes Jazz."
} 
${ }^{x}$ For more discussion of the etymology of the word "jazz," see Porter, and Merriam and Garner. I still maintain that Archie Shepp's explanation is the most plausible and convincing.

${ }^{\text {xi }}$ See Shepp, Mama Rose.

${ }^{\text {xii }}$ See Calmore.

xiii Amiri Baraka's draconically polemical and categorical judgments are well known. My initial reading of his either-or and binary categorizations of "gut bucket" vs. "tail Europe" (in evaluating musicians and their music) as well as "in the tradition" vs. "comprador" or "confused" (meaning NOT "in the tradition") are from articles such as "Afro-American Literature and Class Struggle" and "Afro-American Music and Class Struggle." The latter is from my files and appeared in the now defunct Black Nation Magazine.

${ }^{\text {xiv }}$ My criticism of Baraka's sloppiness encompasses both his literary professionalism and his often outlandish and near-if-not-outright paranoiac proffering. The accusations of irresponsible hyperbole contained in his controversial poem "Somebody Blew Up America" were supported by his own admission that he simply obtained his information from the internet and failed to do any serious factual investigation. In "Why I Believe Betty Shabazz and Diana Spencer [the late Princess Diana] Were Assassinated," commentary about a possible conspiratorial link between the deaths of Betty Shabazz (killed by her grandson) and the automobile collision that killed Princess Diana Spencer disturbingly reads like tabloid conjecture or rant, than either serious investigative journalism or political argument.

${ }^{\mathrm{xv}}$ Kalamu ya Salaam is the Swahili name for "Pen for Peace," he was formerly Vallery Ferdinand, III.

xvi The debate between advocates of Black Nationalism and Marxism ran during the early to mid-1970s with the September 1974 issue being the classic Black Scholar issue for this historic and important ideological struggle.

xvii Kalamu ya Salaam unequivocally renounces Black Nationalism in the essay "Why Do We Lie About Telling the Truth?"

xviii $Z$ Magazine and its attendant small press, South End Press, would propel the publishing careers of bell hooks, Cornel West, Manning Marable-now three of the most well-known and well-paid integrationist democratic-socialist writers/pundits/intellectuals of "color."

xix I believe "Afro-Asian Arts Dialogue" was a name Kalamu ya Salaam proposed from a small conference by that same title and theme organized by dancer/choreographer Peggy Choy during the time of the Los Angeles rebellion in 1992.

${ }^{x x}$ See ya Salaam "'Bird' is a Turkey!"

${ }^{x x i}$ Wynton Marsalis is clearly implicated in my essay "What Makes 'Jazz' the Revolutionary Music of the $20^{\text {th }}$ Century, and Will It Be Revolutionary for the $21^{\text {st }}$ Century?"

xxii Two recent, if the not the first, books devoted entirely to the music-making of Asian Pacific Americans are Wong, and Zheng.

xxiii My description of the Asia Society is paraphrased from conversations with Bill J. Gee and Peter Chow, former directors of Asian Cinevision and Bridge Magazine (an important, though now defunct, national Asian American periodical), both projects operating as Asian American grassroots media organizations based in New York Chinatown.

\section{Works Cited}

Baraka, Amiri. "Afro-American Literature \& Class Struggle," Black American Literature Forum 14.1 (Spring 1980): 5-14. 
----. “Somebody Blew Up America." ChickenBones. 2001. Feb. 2006. http://www.nathanielturner.com/somebodyblewupamerica.htm.

----. "Why I Believe Betty Shabazz and Diana Spencer [the late Princess Diana] Were Assassinated." Unity \& Struggle, October/November 1997: 4-5, 14.

The Black Scholar: Journal of Black Studies and Research. 11 Feb. 2006. http://www.theblackscholar.org.

Calmore, John O. "Critical Race Theory, Archie Shepp, and Fire Music: Securing an Authentic Intellectual Life in a Multicultural World," 65 S. Cal. L. Rev. 2129 (1992).

Enter the Dragon. Directed Robert Clouse, 1973.

Forward 3. Getting Together Publications, 1979.

Higashida, Cheryl. “'Not Just a "Special Issue': Gender, Sexuality, and Post-1965 Afro-Asian Coalition Building in the Yardbird Reader and This Bridge Called My Back." Afro/Asia: Revolutionary Political and Cultural Connections between African and Asian Americans. Ed. Fred Ho and Bill V. Mullen. Durham: Duke UP, Forthcoming.

Ho, Fred ed. Legacy to Liberation: Politics and Culture of Revolutionary Asian Pacific America. Oakland, CA: AK Press, 2000.

Ho, Fred. Personal email to Cheryl Higashida. 27 March 2004.

----. "What Makes 'Jazz' the Revolutionary Music of the $20^{\text {th }}$ Century, and Will It Be Revolutionary for the $21^{\text {st }}$ Century?" African American Review. 29.2 (1995): 283-290.

----. A Song for Manong. Asianlmprov Records, no date.

----. Tomorrow is Now! Soul Note 121117-2, 1985.

Ho, Fred, and Bill V. Mullen, eds. Afro/Asia: Revolutionary Political and Cultural Connections Between African and Asian American. Durham, N.C.: Duke UP, Forthcoming.

Kofsky, Frank. Black Nationalism and the Revolution in Music. New York: Pathfinder Press, 1970.

McAdoo, Bill. Pre-Civil War Black Nationalism. New York: D. Walker Press, 1983.

Merriam, Alan P., and Fradley H. Garner. "Jazz-the Word." The Jazz Cadence of American Culture. Ed. Robert G. O'Meally. New York: Columbia UP, 1998. 7-31.

Mullen, Bill. Interview with Kalamu ya Salaam. San Antonio, Texas, 2001.

Porter, Lewis, "Where Did the Word 'Jazz" Come From?" Jazz: A Century of Change. New York: Schirmer Books, 1997. 1-12.

Revolutionary Action Movement (RAM). "The Relationship of Revolutionary Afro-American Movement to the Bandung Revolution," Black Power, Summer-Fall, 1965, from the Robert F. Williams Collection, Box 2, Bentley Historical Library.

Rush Hour. Brett Ratner, director, 1998. 
Rush Hour II. Brett Ratner, director, 2001.

Shange, Ntozake. For Colored Girls Who Have Considered Suicide Once the Rainbow is Enuf. Macmillan Inc., 1977.

Shepp, Archie. Blasé. Affinity (1969) FA 1, 1980.

----. Goin' Home. Horace Parlan. Steeplechase SCCD-31079, 1978.

----. The Magic of Ju-Ju. Impulse! (GRP) MVCI-23036, 1967.

----. Mama Rose. Steeplechase SCS-1169, 1982.

----. Trouble in Mind. Horace Parlan. Steeplechase SCCD-31139, 1980.

Small, Christopher. Music of the Common Tongue: Survival and Celebration in Afro-American Music. London: J. Calder; New York: River Run Press, 1987.

Stalin, Joseph. Dialectical and Historical Materialism. New York: International Publisher, 1940.

Williams, Robert F. Personal Interview. Winter 1977/78.

Wong, Deborah. Speak it Louder: Asian Americans Making Music. New York: Routledge, 2004.

ya Salaam, Kalamu. "Why Do We Lie About Telling the Truth?" Afro/Asia: Revolutionary Political and Cultural Connections Between African and Asian American. Ed. Fred Ho and Bill V. Mullen. Durham, N.C.: Duke University Press, Forthcoming.

----. The Magic of Ju-Ju. Submitted to Third World Press.

ya Salaam, Kalamu, ed. African American Review 29.2 (1995)

X, Malcolm. Malcolm X Speaks: Selected Speeches and Statements. New York: Pathfinder Press, 1965.

X, The Autobiography of Malcolm X. Spike Lee, director, 1992.

Zheng, Su. Claiming Diaspora: Music, Transnationalism, and Cultural Politics in Asian/Chinese America. London: Oxford UP, 2005. 